$$
\begin{gathered}
S B 360 \\
\cdot 166
\end{gathered}
$$





\section{Protection of Fruits, Vegetables, and other Food Products from Injury by Heat. or Cold during Transportation.}

The following various opinions as to the temperatures that are injurious to perishable articles, under different conditions, have been received by the Weather Bureau from the shippers throughout the country in reply to a circular letter on the subject, and are published for the benefit of all concerned:

In the transportation of perishable freight there are three primal objects to be attained:

1. The protection of the shipment from frost or excessive cold.

2. The protection of the same from excessive heat.

3. The circulation of air through the car, so as to carry off the gases generated by this class of freight.

The temperatures at which perishable goods would be danuged vary greatly with different commodities, their condition when shipped, how loug they may be in transit, whether they are kept contimually in motion, etc.

In transporting perishable articles injury can occur from long exposure to a temperature but little below $32^{\circ}$, or from a shorter exposure to a greater cold, so that the duration as well as the intensity of the cold must be considered.

Oranges on the trees will stand a temperature of $26^{\circ}$ for an hour or so, but if exposed to that temperature for four hours will freeze inside.

Oranges slightly frozen, when placed in a cool room and thawed out gradually, are sweetened, and may be considered by some people as improved, but when frozen solid and thawed they have a "sickish" sweet flavor.

When oranges have been frozen they can be thawed without injury by putting them in cold water or tight barrels immediately after arrival, and allowing them to thaw out gradually.

In shipping perishable goods a great deal depends on the condition of the car; if the car is tight and in good shape apples and potatoes will stand a zero temperature.

Irish potatoes in a store, with a cellar under them, will stand a temperature of $10^{\circ}$, and without a cellar a zero temperature will not hurt them.

Articles shipped from the North to the South during winter should be in a perfectly dry condition. 
As a rule, truckers will not haul vegetahles to the ears for shipment when the temperature reaches $20^{\circ}$, or lower, and in no case when it is near $32^{\circ}$, if raining or snowing.

The degree of cold to which perishable goods may be subjected without injury depends on the time the shipment will be on the road, also whether it will be unloaded immediately upon arriving at its destination or allowed to stand twenty-four hours, also direction of shipment, whether toward a cold area or away from it.

Shucked oysters shipped in their own liquor in tight barrels will not spoil if frozen while in transit. Thick or fat clams or oysters will not freeze as readily as lean ones, as the latter contain much more water. Oysters will not freeze as readily as clams. It is safer when oysters or clams in the shell are frozen to thaw them out gradually, in the original package, in a cool place. Clams and oysters in transit through a snowstorm will not freeze as readily as when the weather is fair and a stiff wind prevails.

Canned tomatoes when frozen become stringy, canned fish soft and mushy, lemons black and spotted, olives soft and rancid, pickles soft and unsalable.

The temperature to which lemons, oranges, and bananas may be exposed without damage varies in different localities, and the different temperatures at those points seem to depend a great deal on the moisture.

Shippers and agents concur in the statement that danger in transportation by freezing has been practically eliminated in the shipment of produce by modern methods; the lined car suffices in spring and autumn and usually during the winter, while in extreme weather the Eastman heater car is used. The temperature of the produce when put into the car is quite a factor to be observed. It is also claimed that a car load of produce, like potatoes, will stand a lower temperature when the car is in motion than when at rest.

Fruit should not be subjected to a temperature lower than $35^{\circ}$ or higher than $60^{\circ}$. Wines should not be subjected to a temperature lower than $20^{\circ}$ or higher than $72^{\circ}$.

In ordinary freight cars perishable goods can be shipped with safety with the outside temperature at $20^{\circ}$, and in refrigerator cars at $10^{\circ}$.

If perisliable goods are put in a box car upon a cold day, and they have radiated considerable heat before being shipped, they will not he able to withstand as low a temperature, and here is where the difference as to the degrees of temperature mainly applies.

Fruit wrapped in heavy brown paper will stand $15^{\circ}$ more cold than if not wrapped.

In what are known as refrigerator cars, perishable goods may be safely shipped with a temperature outside of from zero to $10^{\circ}$ below; 
the car first being heated, and when arriving at the end of journey the goods being taken immediately into a warm place without being carted any great distance.

It is not safe to ship olives in any car, unless heated artificially, when the temperature is below $25^{\circ}$.

The better class of refrigerator cars, such as used by the California Fruit Company, will carry all perishable goods safely through temperature as low as $20^{\circ}$ below zero, provided they are not subjected to such temperatures longer than three or four days at a time, while with the ordinary refrigerator cars temperatures of zero are considered dangerous especially if the goods they contain be of the most perishable kind.

Beer can be shipped at an ontside temperature of $10^{\circ}$ if placed in a refrigerator car and the kegs packed in hay or sawdust and fresh stable manure, the packing being 6 inches or more all around.

Eastern grapes bear low temperatures better than California or Malaga.

While a tempcrature as low as freezing $\left(32^{\circ}\right)$ will not injure potatoes for eating purposes, yet they will fail to sprout in the spring.

Roses and cut flowers will not be injured unless the temperature falls to $32^{\circ}$. Roses need as low a temperature as possible without freezing, because they are shipped as buds and would develop if the temperature were high.

It appears to be generally conceded that goods, when free from undue dampness, that is those classed as dry, will stand a much lower degree of temperature without injury.

METHODS EMPLOYED BY SHIPPERS OF PERISHABLE GOODS TO PROTECT THE ARTICLES FROM DAMAGE BY FREEZING, BOTH BY PACKING AND SHIPPING, IN CERTAIN KINDS OF CARS.

Nany of the precautions in packing that may keep out the cold would also keep in the heat, and there is really more clanger, in some instances, from heating, by process of decomposition, than from cold.

In shipping car loads of bananas a man is usually sent in charge to open and close the ventilators.

Precautions taken in shipping are papering, packing in straw or sawdust, boxing, barreling with paper lining, shipping in paper-lined cars, refrigerator cars, and cars heated by steam, stoves, and salimanders.

During cold weather oysters and clams should be shipped in tight barrels lined with paper.

In shipping perishable goods it is well to cover them with two sheets of heavy paper, weighing about $1 \frac{1}{4}$ pounds each. 
Bananas should be put in a paper bag and a heavy canvas bag and then covered with salt hay, but when put in automatic heaters the fruit is packed only in salt hay.

In packing articles in a car for shipment, potatoes are packed in straw, bulkheaded back, center of car left empty, and car filled as high as double lining, while some of the cars have a double bottom.

French mustard and aqua ammonia are packed in sawdust and securely boxed, being careful to allow the sawdust to form a layer between the articles and the side of the box.

Eggs are packed in crates with separate pasteboard divisions with a layer and a cover of oat chaff.

Quinces, apples, onions, and pears are packed in barrels, each layer of barrels covered and resting on straw.

Tomatoes, lemons, and oranges are packed in crates, each layer of crates in the car is covered and rests upon straw, usually bulkheaded back from the door and car full.

Shrubs and fruit trees are laid on straw, covered with it on all sides, and car packer full.

Flowers are packed in moss and car filled.

Flowers, shrubs, and trees should have their roots carefully packed in straw and the roots placed together in two or three piles, so as to protect them; if the roots are killed, they are of a uniform black; if only injured by frost, the root is pinkish in color just below the outer covering; and if sound, they are of a uniform white. Even if of a dark pink color, no damage need result, if the frost is gradually thawed out by the trees being left in the closed car for four or five days, or else put the roots well down in the soil in a horizontal position and thaw out gradually.

Extra precautions are taken with trees, etc., when passing orer mountains, and no shipments are made when the temperature is likely to be zero any where in the higher regions.

Cars containing perishable goods are sometimes, when a north wind is blowing on the prairie, covered with canvas on the north side.

Oranges shipped from Florida to points as far north as Minnesota are started in ventilator cars, which are changed at Nashville to airtight refrigerator cars, the ventilators of which are kept open, provided the temperature remains above $32^{\circ}$, until arrival at $\mathrm{St}$. Louis, from which point the ventilators are closed and the cars made air tight.

In winter time refrigerator car's are used without ice in forwarding goods from the Pacific coast, and in passing through cold belts or stretches of country the hatches are closed, and the cars being lined and with padded doors, the shipment is protected against the outside temperature; but in passing through warmer climates the ventilators 
of the cars are opened in order to prevent the perishable goods from heating and decaying.

Manure is largely used to protect perishable goods, the bottom of the car being thickly covered with it, and in some cases it is put on top of the goods.

To protect goods shipped in an ordinary car, the sides of the car should be protected by heavy paper tacked to the wall and by the addition of an inner board wall a few inches distant from the other one. A car thus equipped and packed with produce surrounded by straw will retain sufficient heat to prevent injury for twenty-four hours, the average air temperature of all parts of the car being at least $12^{\circ}$ higher than that of the outside air.

In shipping potatoes, when the temperature is $12^{\circ}$, or more, below freezing, the rule is to line the barrels with thick paper, and at extremely low temperatures, as a matter of extra precaution, the barrels are covered over the outside with the same kind of paper, which is considered the best known protection from frost.

All products sent loose in a car are packed in straw on all sides, paying particular attention to the packing around doors, and to see that the car is full.

Certain classes of goods, embracing peaches, melons, and grapes, are taken by some railroads in no other way.

To transport potatoes, place an extra floor and sides in the car, leaving an air space of from 4 to 6 inches, then place a stove in the center.

Oranges loaded in ventilated or common cars should be transferred to refrigerator cars when the temperature reaches $10^{\circ}$ above zero. When oranges are transferred to refrigerator cars, or if loaded in ventilated refrigerators, and the ventilation is closed, the car must be iced sufficiently to prevent heating.

Ventilators on cars containing bananas, lemons, and other delicate fruits must be closed at a temperature of $40^{\circ}$.

Cars are warmed by steam from the locomotive when in motion, and by stoves when steam is not available.

Cars after being loaded are carefully inspected as to temperature within, their destination considered, and if the weather is exceedingly cold, or is liable to be, the car is of ten accompanied by an attendant; otherwise it is inspected from time to time on the road.

Oranges in transit, with a falling temperature, the ventilators should be closed when the thermometer reaches $20^{\circ}$, and with a rising temperature the ventilators should be opened when $28^{\circ}$ is reached. For lemons the minimum is $35^{\circ}$ for opening and closing the ventilators, and for bananas, $45^{\circ}$ for opening or closing.

Lined cars, that is, cars lined with tongued and grooved boards on the sides and ends, leaving an air space of about 4 inches, are con- 
sidered the best by heavy shippers of potatoes, as they can be heated by an ordinary stove, and will stand a temperature outside of $20^{\circ}$ below zero, when a man is in charge to keep up the fires.

\section{THE RELATION BETWEEN THE OUTSIDE AIR TEMPERA- TURE AND THE TEMPERATURE WITHIN AN ORDINAPY FREIGHT CAR AND CARS SPECIALLY ADAP'TED TO THE TRANSPORTATION OF PERISHABLE GOODS.}

From six observations taken at intervals of ten minutes it was found that on a warm day, when the mean of the six readings outside was $68^{\circ}$, it was $66^{\circ}$ on the inside of an ordinary freight car, and $63^{\circ}$ inside of an uniced refrigerator car; on a cold day the mean of six observations was $33^{\circ}$ ontside and $35^{\circ}$ inside of an ordinary car, and $38^{\circ}$ inside of a refrigerator car; the car was stationary.

The difference of temperature inside and outside of a car is from $5^{\circ}$ to $15^{\circ}$, depending whether it is an ordinary freight car or refrigerator car, whether lined or not, and whether there are strong winds.

The difference of temperature in a box car and the outside air is from $3^{\circ}$ to $6^{\circ}$, according to how tight the car is built.

Refrigerator cars, immediately upon being opened, showed $31.8^{\circ}$ on coldest day to $40^{\circ}$ on warmest. An Eastman heater showed $75^{\circ}$ at $5^{\circ}$ a. m., while the temperature of air was $55^{\circ}$; fire was put out and at $9.30 \mathrm{a} . \mathrm{m}$. the temperature was $60^{\circ}$.

The relation between air temperature and temperature within a car varies somewhat. Ordinarily a temperature of abont $20^{\circ}$ outside corresponds to a freezing temperature $\left(32^{\circ}\right)$ within the car. The relation between the two is in proportion to the speed of the car. Irith a car standing still the difference is very slight.

Refrigerator cars are the most desirable for shipping, as the difference in temperature within such cars and the outside air amounts to from $15^{\circ}$ to $30^{\circ}$, the sicles being filled in with sawdust and the cars provided with heating apparatus, which permits of shipments heing made in them, however cold the weather might be. For ordinary winter weather, the temperature ranging from $10^{\circ}$ to $30^{\circ}$ above zero, refrigerator cars may be used for shipment to any distance without being heated.

Freight from the Pacific const to the Mississippi Valley, or even to the Atlantic coast has to pass through almost every variety of climate at any time of the year. It is therefore obvions that at one time the temperature inside of the car is materially above the outside temperature, while perhajes a few hours later, it is below.

The difference between the air temperature and that of the inside of an ordinary car depends upon what the car is loaded with; if apples, the difference will be from $10^{\circ}$ to $12^{\circ}$, if potatoes from $15^{\circ}$ to $18^{\circ}$, warmer than when unloaded. 
The lowest and highest temperatures to which perishable goods may be subjected to without injury under the conditions stated.

\begin{tabular}{|c|c|c|c|c|c|}
\hline \multirow[b]{2}{*}{ Perishable goods. } & \multicolumn{3}{|c|}{$\begin{array}{l}\text { Lowest outside } \\
\text { temperature. }\end{array}$} & \multirow{2}{*}{ 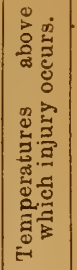 } & \multirow[b]{2}{*}{ Remarks. } \\
\hline & 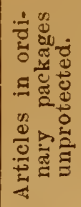 & 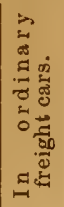 & 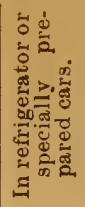 & & \\
\hline & $\circ$ & $\circ$ & $\circ$ & o & \\
\hline Apples, in bbls.. & 20 & Iо & - I0 & 75 & In harrels covered with straw. \\
\hline Apples, loose.... & 28 & I5 & -10 & 75 & Packed in straw. \\
\hline A pricots, haskets.................. & 35 & 24 & 10 & 70 & (a) \\
\hline Aqua amnonia, bbls ................ & 30 & 20 & -10 & & S. \\
\hline Bananas $\ldots \ldots \ldots \ldots \ldots \ldots \ldots \ldots \ldots \ldots$ & 50 & 32 & 20 & 80 & In paper bags; packed in salt hay. \\
\hline Beer or ale, kegs .................. & 25 & 20 & Zero. & 75 & Packed in manure and shavings. \\
\hline Bluing...$\cdots \ldots \ldots \ldots \ldots \ldots \ldots \ldots \ldots \ldots \ldots \ldots$ & 30 & 20 & -10 & & \\
\hline Cabbage in crates. & 30 & 20 & Zero. & 75 & \\
\hline Cantaloupes ....... & 32 & 25 & to & So & \\
\hline 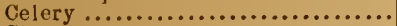 & 30 & 25 & 10 & 65 & In boxes. \\
\hline 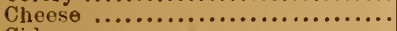 & 30 & 25 & 10 & 75 & \\
\hline Cider ............. & 22 & 18 & -10 & 70 & \\
\hline Clanns............. & 25 & 18 & -10 & ....... & \\
\hline Cranberries ........................ & 28 & 20 & Zero. & $|\ldots \ldots|$ & \\
\hline Cocoanut ......... & 26 & 20 & Zero. & 75 & \\
\hline Urugs (non-alcoholic) $\ldots \ldots \ldots \ldots \ldots$. & 32 & 28 & Zero. & & \\
\hline Eggs, barreled or crated........... & 30 & 20 & Zero. & 80 & \\
\hline Extracts (flavoring)...$\ldots \ldots \ldots \ldots$. & 20 & 15 & Zero. & ....... & \\
\hline 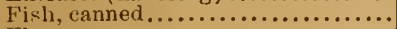 & 18 & 15 & -10 & a..... & \\
\hline 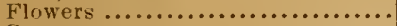 & 35 & 20 & -10 & ...... & Packed in moss. \\
\hline Grapes.......................... & 34 & 20 & Zero. & a..... & Packed in cork. \\
\hline Grape fruit $\ldots \ldots \ldots \ldots \ldots \ldots \ldots \ldots$ & $3^{2}$ & 20 & Zero. & ...... & \\
\hline Groceries, liquid $\ldots . . . \ldots \ldots \ldots \ldots$. & 32 & 20 & Zero. & ....... & \\
\hline 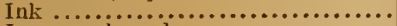 & 20 & 15 & -10 & ...... & \\
\hline Lemons, boxed...$\ldots \ldots \ldots \ldots \ldots$ & - 30 & 20 & & 75 & \\
\hline Lobsters $\ldots \ldots \ldots \ldots \ldots \ldots \ldots \ldots$ & 25 & 20 & Zero. & ....... & \\
\hline Mandarins...$\ldots \ldots \ldots \ldots \ldots \ldots \ldots$ & 32 & 20 & Zero. & 75 & In boxes. \\
\hline Medicines, patent................. & 32 & 28 & Zero. & ....... & Packed in sawdust. \\
\hline Milk ........................... & 32 & 28 & Zero. & 75 & \\
\hline Muvilage........................... & 25 & 15 & Zero. & ...... & \\
\hline 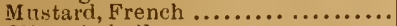 & 26 & 20 & -10 & ...... & \\
\hline Olives in bulk .................... & 28 & 25 & Zero. & ....... & In barrels. \\
\hline Olives in glass.................... & 25 & 20 & Zero. & -..... & \\
\hline Oranges, boxed ................... & 25 & 15 & Zero. & 75 & \\
\hline Onions, boxes $\ldots \ldots \ldots \ldots \ldots \ldots \ldots \ldots$. & 20 & 15 & Zero. & & \\
\hline Oysters in shell, hbls............. & 15 & 10 & -10 & 75 & \\
\hline Oysters, shucked................... & 30 & 20 & Zero. & 70 & Do. \\
\hline 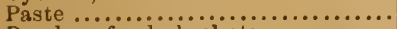 & 32 & 25 & I0 & $\ldots$ & Do. \\
\hline Peaches, fresh, baskets........... & 32 & 20 & 10 & 80 & * \\
\hline Peaches, canned ..................... & 20 & 15 & Zero. & ...... & \\
\hline Pickles in bulk ............. & 22 & 18 & -10 & ...... & Do. \\
\hline Pickles in glass .................. & 20 & 16 & -10 & $\ldots \ldots$ & \\
\hline Pineapples ............................. & 35 & 32 & Zero. & 75 & \\
\hline Plums...$\cdots \cdots \ldots \ldots \ldots \ldots \ldots \ldots \ldots \ldots \ldots$ & 35 & 32 & Zero. & 75 & In boxes with paper. \\
\hline Potatoes, Irish, bbls ............... & 33 & 25 & 10 & 70 & \\
\hline Potatoes, sweet...................... & 35 & 28 & 10 & 80 & In barrels. \\
\hline Shrubs, roses or trees ............. & 35 & 10 & -10 & ...... & In canvas or sacking. \\
\hline Strawberries . . . . . . . . . . . . . . . . & 33 & 25 & -10 & 65 & \\
\hline 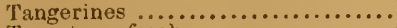 & 25 & 15 & Zero. & 70 & In boxes. \\
\hline Tomatoos, fresh .................... & 33 & 28 & 10 & 90 & \\
\hline Tomatoes, canned ............... & 28 & 25 & -5 & 75 & Do. \\
\hline Vegetables........................ & 33 & 30 & Io & 65 & \\
\hline Vinegar, bbls $\ldots \ldots \ldots \ldots \ldots \ldots \ldots \ldots$ & 22 & 18 & -10 & ....... & \\
\hline Waters, mineral .................... & 28 & 25 & Zero. & ...... & \\
\hline wines, light ...................... & 22 & 15 & Zero. & ...... & \\
\hline Yeast $\ldots \ldots \ldots \ldots \ldots \ldots \ldots \ldots \ldots \ldots \ldots \ldots \ldots \ldots$ & 28 & 25 & Zero. & 65 & \\
\hline
\end{tabular}

\section{U. S. Department of Agriculture,}

Weatifer Bureau,

Washington, D. C., August 22, 1894. 


\section{LIBRARY OF CONGRESS}

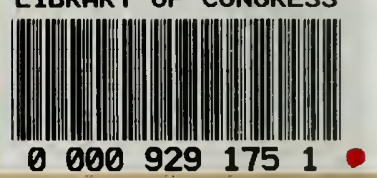

0 0009291751 